\title{
KONSENTRASI NITRAT DAN ORTOFOSFAT DI MUARA SUNGAI BANJIR KANAL BARAT DAN KAITANNYA DENGAN KELIMPAHAN FITOPLANKTON Harmful Alga Blooms (HABs)
}

\author{
Concentration of Nitrate and Orthophosphate at Banjir Kanal Barat Estuary \\ and their Relationship with the Abundance of Harmful Algae Blooms \\ Anggita Wahyuningtyas Tungka, Haeruddin dan Churun Ain \\ Program Studi Manajemen Sumberdaya Perairan \\ Jurusan Perikanan Fakultas Perikanan dan Ilmu Kelautan Universitas Diponegoro \\ J1. Prof. Soedharto, SH Semarang \\ Email: anggitatungka@yahoo.com
}

Diserahkan tanggal 20 Juni 2016, Diterima tanggal 26 Juli 2016

\begin{abstract}
ABSTRAK
Perkembangan industri dan aktivitas rumah tangga di sepanjang aliran Sungai Banjir Kanal Barat Semarang diduga memberikan pengaruh terhadap kualitas perairan berupa buangan limbah yang mengandung nutrien (nitrat dan ortofosfat). Kedua nutrien tersebut dalam konsentrasi yang tinggi dapat mengakibatkan pengkayaan unsur hara (eutrofikasi) dan memicu ledakan populasi fitoplankton (blooming fitoplankton). Kondisi blooming ini diperburuk dengan adanya beberapa spesies fitoplankton yang mengandung racun dalam tubuhnya yang dikenal sebagai Harmful Alga Blooms (HABs). Penelitian dilakukan pada bulan Desember 2015 - Januari 2016 di Muara Sungai Banjir Kanal Barat, dengan tujuan untuk mengetahui konsentrasi nutrien (nitrat dan ortofosfat), jenis dan kelimpahan fitoplankton HABs, serta hubungan dan pengaruh antara konsentrasi nutrien (nitrat dan ortofosfat) terhadap kelimpahan fitoplankton HABs. Metode penelitian yang digunakan adalah metode survey dengan teknik purposive sampling. Hasil penelitian menunjukkan bahwa konsentrasi nitrat di lokasi penelitian berada dalam kisaran 0,6-2,2 mg/l, sedangkan konsentrasi ortofosfat dalam kisaran 0,04$1,3 \mathrm{mg} / \mathrm{l}$. Fitoplankton HABs yang teridentifikasi berjumlah 5 genera diantaranya Trichodesmium sp., Ceratium sp., Noctiluca sp., Pseudonitzschia sp. dan Gonyaulax sp.. Persentase fitoplankton HABs dari total kelimpahan fitoplankton yang teridentifikasi sebesar 40,89\% di stasiun I, $20,10 \%$ di stasiun II dan $11,49 \%$ di stasiun III. Berdasarkan analisis regresi berganda, sebesar 44,2\% nutrien nitrat dan ortofosfat mempengaruhi kelimpahan fitoplankton HABs dengan persentase pengaruh nitrat dan ortofosfat masing-masing sebesar $36,6 \%$ dan $7,6 \%$.
\end{abstract}

Kata kunci: Nitrat, Ortofosfat, Kelimpahan Fitoplankton, Harmful Alga Blooms (HABs), Muara Sungai Banjir Kanal Barat

\section{ABSTRACT}

Industrial and households activity along Banjir Kanal Barat river flow in Semarang allegedly give an impact to the water quality which form the sewage contain nutrients (nitrate and orthophosphate). Both of the nutrients, in high concentration can cause nutrient enrichment (eutrophication) and trigger phytoplankton overpopulation (phytoplankton bloom). Blooming in this condition can be worse because of several toxic phytoplankton, this phenomenon known as Harmful Alga Blooms (HABs). The research was conducted on December 2015 - January 2016 at Banjir Kanal Barat estuary which aimed to knowing the nutrient concentration (nitrate and orthophosphate), find out the abundance of HABs phytoplankton, analyzing the relation of nutrients (nitrate and orthophosphate), and relation between chemical-physics water parameters and the abundance of HABs phytoplankton. The method of this research was used survey by purposive sampling technique. The results of the research showed that nitrate concentrations were in the range of 0.6 to $2.2 \mathrm{mg} / \mathrm{l}$, while orthophosphate concentrations were of 0.04 to $1,3 \mathrm{mg} / \mathrm{l}$. There were 5 generas identified as Phytoplanktons HABs, including Trichodesmium sp., Ceratium sp., Noctiluca sp., Pseudonitzschia sp. and Gonyaulax sp. The phytoplankton HABs percentage from the total abundance of identified phytoplankton was diferent within sampling stations that was 40,89\% at the station I, 20,10\% at the station II and 11,49\% at the station III. Both nitrate and ortophosphate concentration may affected HABs phytoplankton 44,2\% (corelatoin analysis), with the influence of nitrate and orthophosphate were $36,6 \%$ and 7,6\%.

Keywords: Nitrate, Orthophosphate, Phytoplankton Abundance, Harmful Alga Blooms (HABs), Banjir Kanal Barat Estuaries

\section{PENDAHULUAN}

Perkembangan industri dan aktivitas rumah tangga di sepanjang aliran Sungai Banjir Kanal Barat, Semarang secara nyata memberikan masukan bahan pencemar berupa limbah yang mengandung nutrien yang dapat mengakibatkan penurunan kualitas perairan. Limbah dari kegiatan tersebut mengandung beberapa nutrien salah satunya adalah nitrat dan

(ㄷ) Copyright by Saintek Perikanan (Indonesian Journal of Fisheries Science and Technology), ISSN : 1858-4748 
ortofosfat. Konsentrasi yang tinggi dari kedua nutrien ini dapat memicu proses eutrofikasi dan ledakan populasi fitoplankton (blooming).

Peningkatan populasi fitoplankton secara berlebihan (algae bloom) dapat terjadi karena kondisi lingkungan perairan yang mendukung. Ledakan populasi fitoplankton yang diikuti dengan keberadaan beberapa jenis fitoplankton beracun akan menyebabkan ledakan populasi alga berbahaya (Harmful Alga Blooms) (Mulyani et al., 2012). Adanya fitoplankton beracun dapat membahayakan kehidupan organisme perairan. Racun yang terdapat di jaringan tubuh fitoplankton HABs dapat terakumulasi dalam tubuh ikan, kerang, dan udang. Keberadaan toksik dalam organisme tersebut mungkin tidak mematikan organisme retsebut, namun jika dikonsumsi oleh manusia akan menimbulkan gangguan kesehatan atau bahkan kematian.

Spesies fitoplankton HABs yang dapat membahayakan biota laut akibat penurunan oksigen terlarut disebut spesies "anoxious". Dari kelompok ini yang dominan ditemukan di Indonesia adalah dari kelompok Cyanobacterium yaitu Trichodesmium erythraeum. Cyanobacter ini sewaktu-waktu dapat melimpah di perairan karena kondisi unsur hara yang berlebih (Wiadnyana, 1996). Selain Trichodesmium sp., terdapat genus fitoplankton lainnya yang termasuk HABs. Penentuan Fitoplanton HABs lainnya mengacu pada penelitian Wiadnyana (1996) dan GEOHAB (2001), sedangkan penentuan genus fitoplankton mengacu pada Yamaji (1996) dan Sachlan (1982).

Tujuan dilakukannya penelitian ini diantaranya adalah untuk mengetahui konsentrasi nutrien (nitrat dan ortofosfat), jenis dan kelimpahan fitoplankton HABs, serta hubungan dan pengaruh antara konsentrasi nutrien (nitrat dan ortofosfat) terhadap kelimpahan fitoplankton HABs

Keberadaan fitoplankton HABs di perairan dipicu oleh beberapa faktor. Menurut Anderson et al., (2008), faktor yang dapat menyebabkan terjadinya blooming fitoplankton HABs salah satunya adalah eutrofikasi atau pengkayaan unsur hara. Nutrien yang dominan mengakibatkan eutrofikasi adalah nitrat dan fosfat. Kedua unsur ini juga berperan dalam perkembangan fitoplankton.

Kasus kematian massal ikan di Ancol, Jakarta tahun
2015 yang diduga disebabkan oleh kandungan unsur hara (nitrat dan ortofosfat) menjadi latar belakang penelitian ini dilaksanakan. Dilihat dari karakteristiknya, Teluk Jakarta dan Teluk Semarang memiliki morfologi yang sama yaitu perairan yang semi tertutup. Hal ini memungkinkan kasus blooming fitoplankton HABs terjadi di lokasi penelitian.

\section{METODE PENELITIAN}

\section{Materi}

Materi penelitian ini adalah fitoplankton yang diperoleh dari beberapa titik di Muara Sungai Banjir Kanal Barat pada bulan Desember 2015- Januari 2016. Beberapa paramater kualitas air yang diamati meliputi parameter fisika (temperatur air, kecerahan, arus, TSS) dan parameter kimia (konsentrasi nitrat dan ortofosfat, $\mathrm{pH}, \mathrm{DO}$, dan salinitas). Identifikasi fitoplankton dilakukan di Laboratorium Pengelolaan Sumber Daya Ikan dan Lingkungan, Fakultas Perikanan dan Ilmu Kelautan, Universitas Diponegoro, Semarang.

\section{Metode}

Metode yang digunakan dalam penelitian ini adalah metode survey dengan jenis penelitian deskriptif yang mengacu pada Sugiono (1999). Pengambilan sampel fitoplankton dilaksanakan pada 3 stasiun pengamatan. Penentuan stasiun mengunakan metode purposive sampling yang mengacu pada Zulnaidi (2007). Stasiun I terletak di bawah jembatan penyeberangan Yos Sudarso, yang merupakan batas pengaruh pasang-surut air laut. Stasiun II terletak di muara Sungai Banjir Kanal Barat, Semarang. Stasiun III terletak di daerah laut yang masih terpengaruh oleh peristiwa pasang-surut. Pengambilan sampel dilakukan dengan menggunakan metode sampling pasif dengan menyaring 1001 air di masing-masing stasiun pengamatan dengan plankton net ukuran 25 mikron. Pengulangan yang dilakukan pada setiap stasiun sebanyak tiga kali. Sampel air hasil penyaringan dimasukkan dalam botol sampel $50 \mathrm{ml}$ kemudian diberikan larutan lugol-iodin $4 \%$ sebanyak $1 \mathrm{ml}$. Kelimpahan fitoplankton dihitung menggunakan alat pencacah Sedgwick-rafter. Lokasi penelitian dapat dilihat pada Gambar 1.

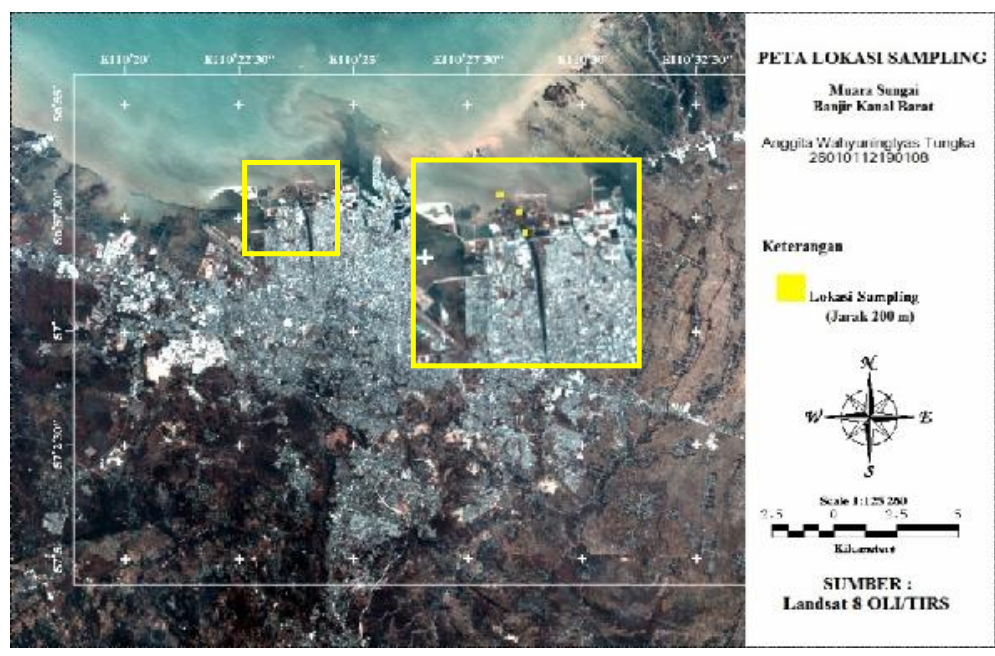

Gambar 1. Lokasi Penelitian

(ㄷ) Copyright by Saintek Perikanan (Indonesian Journal of Fisheries Science and Technology), ISSN : 1858-4748 


\section{Analisis Data}

Kelimpahan Fitoplankton

Perhitungan jumlah plankton per liter, digunakan rumus APHA (1989), yaitu :

$$
\mathrm{N}=\frac{\mathrm{T}}{\mathrm{L}} \mathrm{X} \frac{\mathrm{P}}{\mathrm{p}} \mathrm{X} \frac{\mathrm{V}}{\mathrm{p}} \mathrm{X} \frac{1}{\mathrm{w}}
$$

Keterangan :

$\mathrm{N}=$ Jumlah fitoplankton per liter

$\mathrm{T}=$ Luas gelas penutup $\left(\mathrm{mm}^{2}\right)$

$\mathrm{L}=$ Luas lapang pandang $\left(\mathrm{mm}^{2}\right)$

$\mathrm{P}=$ Jumlah fitoplankton yang tercacah

$\mathrm{p}=$ Jumlah lapang pandang yang diamati

$\mathrm{V}=$ Volume sampel yang tersaring $(\mathrm{ml})$

$\mathrm{v}=$ Volume sampel fitoplankton di bawah gelas penutup $(\mathrm{ml})$

$\mathrm{w}=$ Volume sampel fitoplankton yang disaring (liter)

Sebagian faktor dari rumus tersebut telah diketahui pada sedgewick-rafter, seperti : $\mathrm{T}=1000 \mathrm{~mm}^{2}, \mathrm{v}=1 \mathrm{ml}$, dan $\mathrm{L}=$ $0,25 \mu \mathrm{mm}^{2}$ (dimisalkan satu lingkaran sama dengan luas lapang pandang pada mikroskop dengan $r=0,5 \mathrm{~mm}$ ), maka rumus tersebut menjadi :

$$
\begin{gathered}
\mathrm{N}=\frac{1000 \mathrm{~mm} 2}{0,25 \pi} \times \frac{\mathrm{p}}{10} \times \frac{\mathrm{v}}{1 \mathrm{ml}} \times \frac{1}{\mathrm{w}} \text { atau } \\
\mathrm{N}=\frac{100(\mathrm{Px})}{0.25 \pi \mathrm{w}}
\end{gathered}
$$

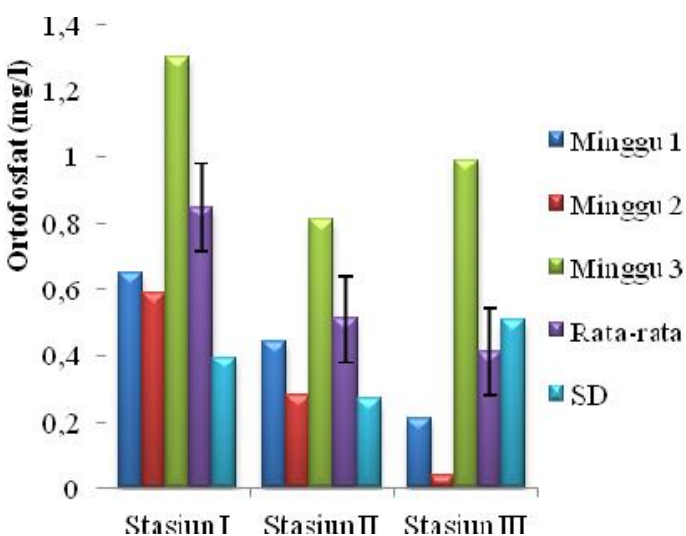

Analisis nitrat fosfat menggunakan metode spektofotometri.

\section{Uji Korelasi Berganda}

Data yang digunakan untuk dianalisis dengan metode korelasi adalah data konsentrasi nitrat dan ortofosfat sebagai variabel bebas (dependen) dan kelimpahan fitoplankton HABs sebagai variabel tak bebas (independen) dengan persamaan $\mathrm{Y}=\mathrm{a}+\mathrm{b} \mathrm{X}_{1}+\mathrm{c} \mathrm{X}_{2}$. Data tersebut dianalisis untuk mengetahui seberapa besar keeratan hubungan dan pengaruh variabel dependen terhadap variabel independen. Aplikasi yang digunakan adalah SPSS (Statistical Product and Service Solution) versi 16. Menurut Mulyani et al., (2012), uji korelasi digunakan untuk mengetahui hubungan antar parameter lingkungan terhadap kepadatan fitoplankton HABs.

\section{HASIL DAN PEMBAHASAN}

\section{Konsentrasi Nitrat dan Ortofosfat}

Konsentrasi nitrat dan ortofosfat di muara Sungai Banjir Kanal Barat berada dalam kisaran 0,80-2,20 mg/l, sedangkan konsentrasi ortofosfat berada dalam kisaran 0,04-1,30 mg/l. Histogram konsentrasi nitrat dan ortofosfat di lokasi penelitian dapat dilihat pada Gambar 1.

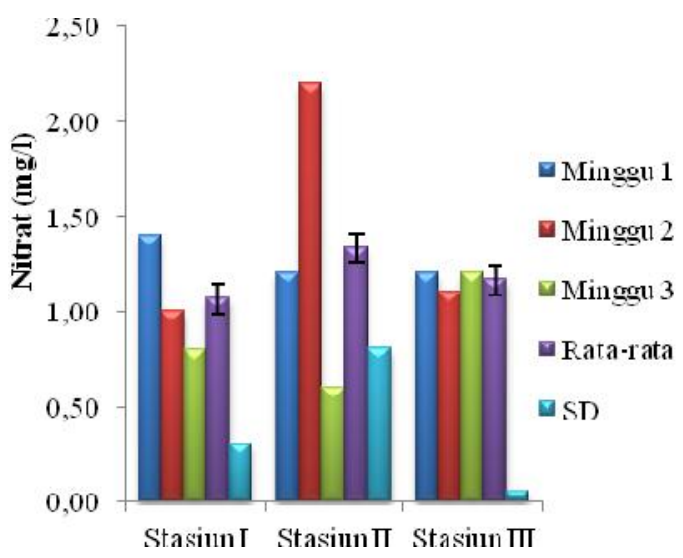

Gambar 1. Histogram konsentrasi nitrat $\left(\mathrm{NO}_{3}\right)$ dan ortofosfat $\left(\mathrm{PO}_{4}\right)$ di lokasi penelitian
Konsentrasi nitrat tertinggi di lokasi penelitian berada di stasiun II pada setiap pengulangan yaitu berkisar antara 1,20$2,20 \mathrm{mg} / \mathrm{l}$. Salah satu faktor yang menyebabkan tingginya konsentrasi nitrat di stasiun ini kemungkinan karena adanya buangan limbah rumah tangga dari perumahan di sekitar Pantai Marina. Menurut Brigden dan Stringer (2000), limbah dengan kandungan amonia sebagaian besar bersumber dari sekresi mamalia dalam bentuk urin, pabrik pupuk nitrogen, pabrik ammonia dan pabrik asam nitrat. Faktor lingkungan lainnya yang dapat mempengaruhi konsentrasi nitrat di perairan adalah pupuk pertanian dan erosi.

Konsentrasi ortofosfat tertinggi di muara Sungai Banjir Kanal Barat Semarang terdapat di stasiun I. Pada pengulangan minggu pertama sebesar $0,65 \mathrm{mg} / \mathrm{l}$, pengulangan minggu kedua turun menjadi $0,59 \mathrm{mg} / \mathrm{l}$ dan pengulangan minggu ketiga naik menjadi $1,30 \mathrm{mg} / \mathrm{l}$. Tingginya konsentrasi ortofosfat di stasiun I dikarenakan adanya pompa Bulu's Drain Semarang yang membuang limbah rumah tangga dari permukuman penduduk setempat berupa deterjen. Deterjen dapat meningkatkan konsentrasi ortofosfat karena ion ini merupakan salah satu komposisi penyusunnya.

Deterjen umumnya tersusun atas tiga komponen utama yaitu, surfaktan (sebagai bahan dasar deterjen), bahan builders (senyawa fosfat) dan bahan aditif (pemutih dan pewangi). Komponen terbesar dari deterjen yaitu bahan builders berkisar 70-80 \%, bahan dasar surfaktan berkisar 20-30\%, dan bahan aditif relatif sedikit yaitu antara 2-8\% (Sawyer and Carty, 1978 dalam Sopiah dan Chaerunisah, 2006). Senyawa fosfat yang digunakan oleh semua merek deterjen memberikan andil yang cukup besar terhadap terjadinya proses eutrofikasi yang menyebabkan blooming algae (meledaknya populasi alga).

Menurut Effendi (2003), pertumbuhan fitoplankton tergantung pada tinggi rendahnya kadar nitrat dan fosfat di perairan. Rasio kadar N:P (Redfield ratio) di perairan alami

(C) Copyright by Saintek Perikanan (Indonesian Journal of Fisheries Science and Technology), ISSN : 1858-4748 
adalah 16:1, yang dapat digunakan fitoplankton untuk tumbuh optimal. Kadar nitrat yang melebihi $0,2 \mathrm{mg} / \mathrm{l}$ dapat mengakibatkan terjadinya eutrofikasi (pengayaan) perairan yang selanjutnya memacu pertumbuhan alga dan tumbuhan air secara pesat (blooming). Berdasarkan data konsentrasi nitrat di lokasi penelitian, stasiun III berpotensi mengalami peristiwa blooming fitoplankton karena konsentrasinya yang melebihi rasio kadar N:P di perairan. Rasio konsentrasi nitrat dan ortofosfat di stasiun III yang tinggi menjadikan kelimpahan fitoplankton di stasiun ini paling tinggi dibandingkan dengan stasiun pengamatan lainnya yakni sebesar $34.182 \mathrm{ind} / \mathrm{l}$.

Fitoplankton memanfaatkan nutrien nitrat sebagai bahan dasar pembuatan bahan organik yang menjadi sumber makanan primer yang berada di rantai makanan di laut dengan bantuan sinar matahari. Hal ini yang menyebabkan fitoplankton disebut juga sebagai primary producer. Namun konsentrasi nitrat yang dimanfaatkan fitoplankton memiliki batas tertentu, konsentrasi nitrat yang melebihi batas yang dimanfaatkan dapat memicu peristiwa pengkayaan nutrien atau yang lebih dikenal dengan eutrofikasi. Menurut Nurlita dan Utomo (2011), unsur-unsur nitrogen seperti $\mathrm{NH}_{4}, \mathrm{NO}_{3}$, dan $\mathrm{NO}_{2}$ dapat menyebabkan eutrofikasi. Peristiwa eutrofikasi ini dapat menyebabkan suatu kondisi yang disebut dengan alga blooming dikarenakan terlalu banyak unsur hara untuk menghasilkan alga tersebut. Eutrofikasi ini dapat dikatakan merusak ekosistem sekitarnya karena supply oksigen yang berada di perairan tersebut berkurang atau bahkan dikatakan tidak ada, dan pada akhirnya

dapat mengganggu proses kehidupan di sekitar laut.

\section{Jenis dan Kelimpahan Fitoplankton HABs}

Berdasarkan hasil identifikasi yang telah dilakukan, jenis fitoplankton yang terdapat di muara Sungai Banjir kanal Barat terdiri dari 5 kelas yaitu Bacillariophyceae, Cyanophyceae, Dinophyceae, Mediophyceae, dan Dictiochophyceae. Kelimpahan genera fitoplankton yang mendominasi adalah dari kelas Bacillariophyceae yang berjumlah 16 genera pada pengulangan pertama, 15 genera pada pengulangan kedua, dan 13 genera pada pengulangan ketiga.

Hal ini disebabkan karena diatom (Bacillariophyceae) merupakan jenis yang paling penting dan umum terdapat perairan payau sampai laut. Menurut Perry (1994) dalam Muhiddin (2009), jenis-jenis fitoplankton dalam kelas Bacillariophyceae mempunyai sifat yang mudah beradaptasi dengan lingkungan, bersifat kosmopolit, tahan terhadap kondisi yang ekstrim dan mempunyai daya reproduksi yang tinggi.

Spesies fitoplankton HABs yang berhasil teridentifikasi sebanyak 5 genera. Lima genera tersebut diantaranya adalah Noctiluca sp., Pseudonitzschia sp., Trichodesmium sp., Ceratium sp. dan Gonyaulax sp. Genus fitoplankton HABs yang dominan ditemukan adalah Trichodesmium sp. yang termasuk kedalam kelas Cyanophyceae.

Persentase fitoplankton HABs di lokasi penelitian sebanyak 3 (tiga) kali pengulangan dapat dilihat pada Gambar 3.

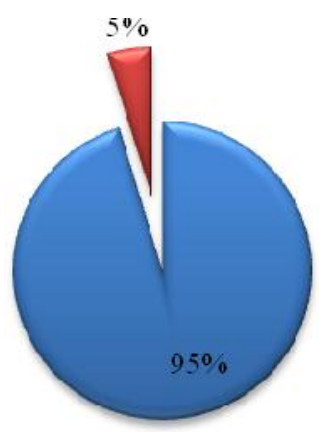

Stasiun I

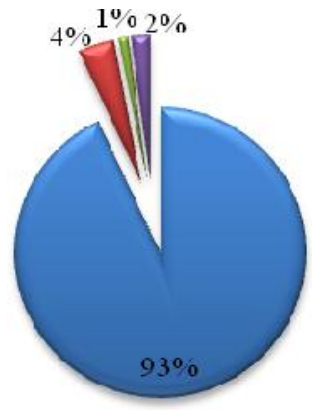

Stasiun II

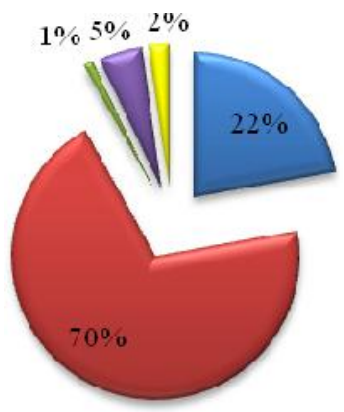

Stasiun III

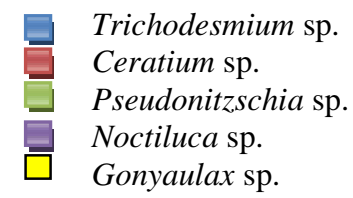

Gambar 3. Persentase fitoplankton HABs di masing-masing stasiun penelitian

Berdasarkan Gambar 3. spesies Trichodesmium sp. memiliki persentase yang paling tinggi pada stasiun I dan II yaitu 95\% dan 93\%, sedangkan pada stasiun III spesies fitoplankton $\mathrm{HABs}$ dengan kelimpahan tertinggi adalah Ceratium sp. Hal ini menunjukkan bahwa spesies HABs yang dominan ditemukan di setiap stasiun dan setiap pengulangan yang dilakukan adalah Trichodesmium sp. Spesies umumnya berbentuk silinder panjang dan terdapat sekat. Beberapa kali dijumpai dalam bentuk koloni namun lebih sering teridentifikasi dalam bentuk soliter. Menurut Sediadi (2004), jenis Trichodesmium spp. ini berbentuk koloni berperan penting dalam terjadinya proses biogeokimia di perairan laut. Distribusi jenis Trichodesmium spp. dijumpai di perairan laut subtropik sampai perairan laut tropik. Karakteristik lain Trichodesmium spp. yang harus diwaspadai adalah pada saat melimpah (blooms) di perairan tropis, yaitu dapat menyebabkan kurangnya kandungan oksigen sehingga terjadi

(C) Copyright by Saintek Perikanan (Indonesian Journal of Fisheries Science and Technology), ISSN : 1858-4748 
Konsentrasi Nitrat dan Ortofosfat di Muara Sungai Banjir Kanal Barat dan Kaitannya dengan Kelimpahan Fitoplankton Habs

proses pembusukan yang akhirnya dapat menimbulkan kematian biota laut, seperti ikan.

Berdasarkan data yang diperoleh, kelimpahan fitoplankton Trichodesmium sp. setiap pengulangan mengalami peningkatan yang besar. Pada pengulangan pertama dijumpai sebesar 1422 ind/l kemudian naik menjadi 3609 ind/l pada pengulangan kedua dan naik menjadi 5860 ind/l pada pengulangan ketiga. Peningkatan yang signifikan pada pengulangan ketiga ini menimbulkan dampak penurunan oksigen terlarut yang sangat besar. Pada pengulangan pertama dan kedua konsentrasi oksigen terlarut di lokasi penelitian berada dalam kisaran 4-6 mg/l kemudian pada pengulangan ketiga turun menjadi 2-4 mg/l.

Ceratium sp. merupakan genera fitoplankton HABs tertinggi kedua yang didapatkan dengan kisaran kepadatan 361 -2441 ind/1. Ledakan populasi Ceratium sp. dapat mengakibatkan kematian massal biota laut akibat penurunan kadar oksigen.. Dikutip dari GEOHAB (2001), Ceratium furca mampu berkompetisi dengan spesies fitoplankton lain, terutama dalam hal ketersediaan nutrisi, cahaya matahari, dan faktor lingkungan lain. Ceratium furca sering ditemukan dalam jumlah melimpah dan mendominasi spesies lain. Oleh karena itu, C. furca lebih sering blooming, yang mengakibatkan kematian massal organisme laut karena terjadi deplesi oksigen pada perairan.

Genera fitoplankton HABs lainnya yang teridentifikasi di lokasi penelitian adalah Pseudonitzscia sp. dari kelas Bacillariophyceae. Kelimpahan fitoplankton Pseudonitzscia sp. mengandung asam domoat yang dapat memberikan dampak buruk bagi perairan karena jika dikonsumsi kerang atau udang maka akan mengakibatkan penyakit amnestic shellfish poisoning (ASP) bagi manusia yang mengkonsumsi. Menurut Jeffery (2004) dalam Rengganis et al., (2011) produksi asam domoat (domoic acid) merupakan respon dari tekanan Tabel 1. Nilai koefisien krelasi dan determinasi lingkungan seperti berubahnya temperatur. Jika dikonsumsi oleh mamalia, asam domoat tersebut akan menggantikan neurotransmitter yang menyebabkan penyakit ASP, dimana asam domoat tersebut dapat mengakibatkan depolariasi dan meningkatkan permeabilitas ion kalsium dalam tubuh sehingga dapat menyebabkan kematian sel.

Genera fitoplankton HABs lainnya yang ditemukan adalah Gonyaulax sp. dengan kisaran kelimpahan 21-85 ind/l. Salah satu jenis fitoplankton dari genera ini yaitu Protogonyaulax sp. yang banyak ditemukan dalam tubuh kerang dan menyebabkan penyakit paralytic shellfish poisoning (PSP). Menurut Wiadnyana (1996), Kelimpahan fitoplankton dapat dikategorikian sebagai blooming apabila populasinya mendominasi $90 \%$ dari total kelimpahan fitoplankton di suatu perairan. Kepadatan Gonyaulax sp. yang tinggi di perairan akan menimbulkan peristiwa pasang merah (red tide). PSP dapat mengakibatkan gejala keracunan ringan dan keracunan berat. Keracunan ringan ditandai dengan badan terasa gatal-gatal atau panas, bibir terasa tebal kemudian merambat ke bagian muka, kesemutan pada ujung jari tangan dan jari kaki, sakit kepala, pusing-pusing, mual, muntah dan diare pada 30 menit pertama. Keracunan berat ditandai dengan tidak dapat bergerak (paralisis), susah bernafas (terasa tercekik), sistem pernafasan terhambat dan dapat mengakibatkan kematian.

\section{Keterkaitan Konsentrasi Nitrat dan Ortofosfat dengan Kelimpahan Fitoplankton HABs}

Data yang diolah dengan menggunakan analisis korelasi dengan aplikasi SPSS digunakan untuk mengetahui seberapa besar pengaruh nutrien nitrat dan ortofosfat terhadap kelimpahan fitoplankton HABs. Hasil yang diperoleh dapat dilihat pada Tabel 1 dan Tabel 2.

\begin{tabular}{|c|c|c|c|c|c|c|}
\hline \multicolumn{7}{|c|}{ Model Summary ${ }^{b}$} \\
\hline Model & $\mathbf{R}$ & \multirow{2}{*}{$\frac{\text { R Square }}{.442}$} & $\begin{array}{c}\text { Adjusted } R \\
\text { Square }\end{array}$ & $\begin{array}{c}\text { Std. Error of the } \\
\text { Estimate }\end{array}$ & \multicolumn{2}{|c|}{ Durbin-Watson } \\
\hline 1 & $.665^{\mathrm{a}}$ & & .25 & 794.62328 & & 2.225 \\
\hline \multicolumn{7}{|c|}{ ANOVA $^{b}$} \\
\hline & Model & Sum of Squares & df & Mean Square & $\mathbf{F}$ & Sig. \\
\hline \multirow[t]{3}{*}{1} & Regression & 3004657.042 & 2 & 1502328.521 & 2.379 & .173 \\
\hline & Residual & 3788556.958 & 6 & 631426.160 & & \\
\hline & Total & 6793214.000 & 8 & & & \\
\hline
\end{tabular}

Berdasarkan Tabel 1, dengan mengunakan taraf kepercayaan $80 \%(\alpha=0,2)$ nilai koefisien korelasi (R) sebesar 0,665. Nilai ini memberikan informasi bahwa hubungan nutrien nitrat dan ortofosfat termasuk dalam kategori kuat. Sedangkan nilai koefisien determinasi $\left(\mathrm{R}^{2}\right)$ sebesar 0,442 . Hal ini memberikan informasi bahwa sebesar 44,2\% kelimpahan fitoplankton Tabel 2. Nilai persamaan linier
HABs dipengaruhi oleh konsentrasi nitrat dan ortofosfat sedangkan 55,8\% lainnya dipengaruhi oleh faktor parameter fisika kimia perairan seperti temperatur, salinitas, oksigen terlarut dan lainnya. Menurut Rahmawati et al., (2014), kelimpahan fitoplankton pada suatu perairan selalu berkaitan erat dengan kondisi di sekitar lingkungan perairan tersebut.

\begin{tabular}{llrrr}
\hline \multirow{2}{*}{ Model } & & \multicolumn{2}{c}{ Unstandardized Coefficients } & \multicolumn{1}{c}{ Correlations } \\
\cline { 3 - 5 } 1 & & B & Std. Error & Zero-order \\
\hline & Kelimpahan & 2559.827 & 1058.595 & \\
& Nitrat & -930.018 & 560.578 & -.646 \\
& Ortofosfat & 407.112 & 786.068 & .432 \\
\hline
\end{tabular}

(ㄷ) Copyright by Saintek Perikanan (Indonesian Journal of Fisheries Science and Technology), ISSN : 1858-4748 
Berdasarkan Tabel 2 persamaan model linier yang diperoleh yaitu $\mathrm{Y}=25560-930$ Nitrat +407 Ortofosfat. Uji koefisien determinasi parsial dilakukan untuk mengetahui besarnya pengaruh masing-masing nutrien nitrat dan ortofosfat terhadap kelimpahan fitoplankton dilakukan. Perhitungan dengan menggunakan formula Beta x Zero Order. Beta adalah koefisien regresi yang telah distandarkan, sedangkan Zero Order merupakan determinasi parsial dari setiap variabel bebas terhadap variabel terikat. Hasil yang diperoleh sebesar 36,6\% untuk nitrat dan 7,6\% untuk ortofosfat. Hal ini menunjukkan bahwa pengaruh nitrat terhadap kelimpahan fitoplankton HABs jauh lebih besar. Hal ini diperkuat oleh Anderson et al., (2002), nitrat seringkali menjadi faktor pembatas utama dalam produktifitas primer fitoplankton di muara.
Sebanyak 5 genera fitoplankton yang berhasil teridentifikasi selama penelitian, spesies yang paling terpengaruh terhadap perubahan konsentrasi nutiren nitrat dan ortofosfat adalah jenis Trichodesmium sp. Hal ini dibuktikan sengan nilai koefisien korelasi sebesar 0,720 memberikan informasi bahwa pengaruh nutrien nitrat dan ortofosfat terhadap kelimpahan Trichodesmium sp. Termasuk kuat. Jika nilai koefisien korelasi mendekati angka 1 maka konsentrasi nutrien nitrat dan ortofosfat terhadap kelimpahan Trichodesmium sp. memiliki hubungan yang kuat. Nilai koefisien determinasi $\left(\mathrm{R}^{2}\right)$ sebesar 0,518 yang berarti pengaruh nutrien nitrat dan ortofosfat terhadap kelimpahan Trichodesmium sp.sebesar $52 \%$. Luaran hasil analisis korelasi spesies Trichodesmium sp. dapat dilihat pada Tabel 3.

Tabel 3. Nilai Koefisien Korelasi Spesies Trichodesmium sp.

\begin{tabular}{cccccc}
\hline Model & $\mathbf{R}$ & $\mathbf{R}^{2}$ & Adjusted $\mathbf{R}^{2}$ & Std. Error of the Estimate & $\begin{array}{c}\text { Durbin- } \\
\text { Watson }\end{array}$ \\
\hline 1 & 0,720 & 0,518 & 0,358 & 837,53214 & 1,786 \\
\hline
\end{tabular}

Berdasarkan Tabel 3. spesies fitoplankton yang teridentifikasi di muara Sungai Banjir Kanal Barat, Semarang yang cenderung paling sensitif terhadap perubahan konsentrasi nitrat dan ortofosfat adalah spesies Trichodesmium sp.. Spesies ini juga merupakan spesies yang mendominasi kelimpahan fitoplankton di lokasi tersebut. Hal yang dapat mempengaruhi tingginya kelimpahan Trichodesmium sp. salah satunya adalah kemampuan spesies ini yang dapat mengikat unsur nitrat di perairan sehingga mudah memperbanyak populasinya dalam waktu yang singkat. Manurut penelitian Mohanty et al., (2010) yang dilakukan di Kalpakkam, India, spesies Trichodesmium sp. memiliki kemampuan untuk memfiksasi nitrogen dalam bentuk ammonium.

Pada tanggal 31 Oktober 1982 di Teluk Jakarta terjadi blooming spesies Trichodesmium sp. yang semula diduga sebagai tumpahan minyak. Keesokan harinya terjadi pembusukan fitoplankton ini yang kemudian diikuti kematian sejumlah ikan, cacing, dan hewan lainnya. Demikian pula pada tanggal 20 Agustus 1984 pada ekspedisi SNELIUS II di Laut Arafura dilaporkan terjadi blooming Trichodesmium sp. Pada saat itu air relatif tenang dan terlihat hamparan luas berwarna kecoklatan seperti serbuk gergaji. Dari contoh gumpalan tersebut setelah diperiksa adalah spesies Trichodesmium sp. yang mencapai kelimpahan $97,45 \%$ dari seluruh populasi di perairan tersebut (Adnan, 1985).

\section{KESIMPULAN}

1. Konsentrasi nitrat masing- masing stasiun di muara Sungai Banjir Kanal Barat Semarang berada dalam kisaran 0,8-1,4 mg/l pada stasiun I, 0,6-2,2 mg/l pada stasiun II, dan 1,1-1,2 mg/l pada stasiun III, sedangkan konsentrasi ortofosfat berada dalam kisaran 0,58-1,3 mg/l pada stasiun I, 0,28-0,81 mg/l pada stasiun II, dan 0,04$0,99 \mathrm{mg} / \mathrm{l}$ pada stasiun III;

2. Jenis fitoplankton HABs yang teridentifikasi di lokasi penelitian diantaranya adalah Trichodesmium sp., Ceratium sp. Noctiluca sp., Pseudonitzschia sp., dan Gonyaulax sp. Kelimpahan fitoplankton di stasiun I berjumlah 15.584 ind/l dan $41 \%$ diantaranya adalah

(C) Copyright by Saintek Perikanan (Indonesian Journal of Fisheries Science and Technology), ISSN : 1858-4748 fitoplankton HABs, stasiun II berjumlah 21.019 ind/l dan $20 \%$ diantaranya adalah fitoplankton HABs, dan stasiun III berjumlah 34.182 ind/1 dan $12 \%$ diantaranya adalah fitoplankton HABs; dan

3. Hasil uji korelasi menunjukkan adanya hubungan yang nyata antara nitrat dan ortofosfat terhadap kelimpahan fitoplankton HABs sebesar 0,66. Sebesar 44,2\% konsentrasi nitrat dan ortofosfat mempengaruhi kelimpahan fitoplankton HABs. Pengaruh nutrien nitrat dan ortofosfat masing-masing sebesar $36,6 \%$ dan $7,6 \%$. Spesies fitoplankton HABs yang teridentifikasi di lokasi penelitian yang paling sensitif terhadap perubahan kedua nutrien tersebut adalah jenis Trichodesmium sp.

\section{UCAPAN TERIMA KASIH}

Penulis mengucapkan terima kasih kepada, Prof. Dr. Ir. Sahala Hutabarat, M.Sc, Drs. Ign. Boedi Hendrarto, M.Sc, Ph.D, dan Dr. Ir. Djoko Suprapto, M.Sc. yang telah memberikan saran dan kritik dalam penulisan artikel ini. Serta semua pihak yang telah memberikan dukungan sehingga penulis dapat menyelesaikan artikel ini.

\section{DAFTAR PUSTAKA}

Adnan, Q. 1985. Red Tide. Jurnal Oseana, X (2):48-55.

Anderson, D,M., J,M, Burkholder., W,P, Cochlan., P,M, Gilbert., C,J, Gobler., C,A, Heil., R,M, Kudela., M,L, Parsons., J,E, Jack Rensel., D,W, Townsend., V,L, Trainer., G,A, Vargo. 2008. Harmful Algall Blooms And Eutrophication: Examining Linkages From Selected Coastal Region of The United Stated, Harmful Algae. 23 p.

APHA (American Public Health Association).1989. Standard Method for the Examinition of Water and Waste Water. American Public Health Association. Water Pollution Control Federation. Port City Press. Baltimore, Mariland.1202 p. 
Konsentrasi Nitrat dan Ortofosfat di Muara Sungai Banjir Kanal Barat dan Kaitannya dengan Kelimpahan Fitoplankton Habs

Brigden, K. and Stringer, R. 2000. Ammonia and Urea Production : Incidents of Ammonia Release From The Profertil Urea and Ammonia Facility, Bahia Blanca, Argentina, Greenpeace Research Laboratories, Departement of Biological Science University of Exeter, UK, 334 p.

GEOHAB. 2001. Global Ecology and Oceanography of Harmful Algal Bloom Science Plan. SCOR and IOC, Paris, 86 p.

Mohanty, A.K, K.K. Salphaty, G. Sahu, K.J. Husain, M.V.R. Prasad dan S.K Sakar Bloom of Trichodesmium erythraeum (Ehr) And Its Impact On Water Quality And Plankton Community Structure In Coastal Waters Of Southeast Of India. Indian Juurnal of Marine Science. 39 (3): 323-333.

Muhiddin, A.H. 2009. Pemetaan Distribusi Vertikal Kelimpahan Fitoplankton Secara Temporal dan Spasial di Perairan Timur Pulau Barrang Lompo Kota Makassar.Jurnal Ilmu Kelautan, FPIK Universitas Hasanuddin Makassar.

Mulyani, Riani, W., Wisnu W. 2012. Sebaran Spasial Spesies Penyebab Harmful Algal Blooms (HABs) di Lokasi Budidaya Kerang Hijau (Perna viridis) Kamal Muara, Jakarta Utara pada Bulan Mei 2011. Jurnal Akuatika. 3 (1):28-39.

Nurlita, H dan Sudarno U. 2011. Potensi Nitrikasi Oleh Bakteri yang Terdapat di Laut Aliran Kali Plumbon, Laut Aliran Kali Banjir Kanal Barat dan Laut Aliran Kali Banjir Kanal Timur. Jurnal Presipitasi. VIII (1):187-198.
Effendi, H. 2003. Telaah Kualitas Air Bagi Pengelolaan Sumber Daya dan Lingkungan Perairan. Kansisius, Jogjakarta, $258 \mathrm{hlm}$.

Rahmawati, I, B. Hendrarto, P.W. Purnomo. 2014. Fluktuasi Bahan Organik Dan Sebaran Nutrien Serta Kelimpahan Fitoplankton Dan Klorofil-A Di Muara Sungai Sayung Demak. Journal Of Maquares (3) 1: 27-36

Rengganis, D.D, Ainurohim dan H. Thoha. 2011. Fitoplankton Penyebab Harmful Algae Blooms (HABs) di Perairan Teluk Jakarta. Institut Teknologi Sepuluh Nopember, Surabaya

Sediadi, A. 2004. Dominasi Cyanobacteria pada Musim Peralihan di Perairan Laut Banda dan Sekitarnya. Jurnal Makara Sains. VII (1):1-14

Sachlan, M. 1982. Planktonologi. Semarang, Universitas Diponegoro, $112 \mathrm{hlm}$.

Sugiyono, 1999, Statistik untuk Penelitian, Bandung, Alfabeta $124 \mathrm{hlm}$.

Sopiah, N.R. dan Chaerunisah.2006. Laju Degradasi Surfaktan Linear Alkil Benzena Sulfonat (LAS) pada Limbah Deterjen Secara Aerob pada Reaktor Lekat Diam Bermedia Sarang Tawon. Jurnal Teknik Lingkungan. 7 (3): 243-250.

Yamaji, I. 1996. Illustration of the Marine Plankton of Japan. Osaka, Hoikusho.

Zulnaidi. 2007. Metode Penelitian. Departemen Sastra Jepang, Fakultas Sastra. Unversitas Sumatera Utara. Medan, 34 hlm.

() Copyright by Saintek Perikanan (Indonesian Journal of Fisheries Science and Technology), ISSN : 1858-4748 